\title{
Penerapan Model Pembelajaran Problem Based Learning Untuk Meningkatkan Hasil Belajar Pada Mata Pelajaran Geografi Kelas XI IPS 2 SMA Negeri 1 Buntulia Tahun Pelajaran 2019/2020
}

\author{
Idris Djafar \\ Guru SMA Negeri 1 Buntulia \\ idris@gmail.com
}

Received: 04 March 2021; Revised: 26 April 2021; Accepted: 28 July 2021

DOI: http://dx.doi.org/10.37905/aksara.7.3.1215-1222.2021

\begin{abstract}
Abstrak
Penelitian ini bertujuan untuk meningkatkan hasil belajar pada mata pelajaran geografi dengan penerapan model pembelajaran Problem Based Learning (PBL) di kelas XI IPS 2 SMA Negeri 1 Buntulia. Jenis penelitian ini adalah Penelitian Tindakan Kelas (PTK) yang dilakukan dalam dua siklus tindakan. Setiap siklus terdiri dari beberapa tahap yaitu perencanaan, pelaksanaan tindakan, observasi dan refleksi. Siklus pertama membahas tentang materi Fenomena Biosfer dan siklus kedua tentang materi Fenomena Antroposfer. Subyek dalam penelitian ini adalah siswa kelas XI IPS 2 SMA Negeri 1 Buntulia Tahun Pelajaran 2019/2020 yang terdiri dari 34 siswa. Pengumpulan data dilakukan dengan cara observasi, wawancara, dan dokumentasi. Berdasarkan hasil analisis data diketahui bahwa hasil belajar afektif siswa pada siklus I sebesar $62,28 \%$ dan untuk siklus II sebesar 80,58\%. Peningkatan hasil belajar afektif yang terjadi dari siklus I ke siklus II adalah sebesar $18,30 \%$. Selain itu, hasil belajar psikomotor siswa pada siklus I sebesar $60,57 \%$ dan untuk siklus II sebesar $80,29 \%$. Peningkatan hasil belajar psikomotor yang terjadi dari siklus I ke siklus II adalah sebesar $19,72 \%$. Sedangkan, ketuntasan hasil belajar kognitif siswa pada siklus I sebesar $64,71 \%$ dan untuk siklus II sebesar $76,47 \%$. Peningkatan ketuntasan hasil belajar kognitif yang terjadi dari siklus I ke siklus II adalah sebesar $11,76 \%$. Hasil penelitian ini menunjukkan bahwa dengan menerapkan model pembelajaran Problem Based Learning mampu meningkatkan hasil belajar mata pelajaran geografi kelas XI IPS 2 SMA Negeri 1 Buntulia Tahun Pelajaran 2019/2020.
\end{abstract}

Kata Kunci: model pembelajaran problem based learning, hasil belajar

\section{PENDAHULIAN}

Kurikulum yang dipergunakan pada sistem pendidikan saat ini adalah Kurikulum 2013. Dalam Kurikulum 2013 ini pembelajaran lebih difokuskan kepada siswa atau student center sedangkan guru sebagai fasilitator dalam pembelajaran. Dalam hal ini, siswa dituntut lebih aktif dalam pembelajaran sehingga siswa dapat mengembangkan potensinyasecara optimal. Karena pendidikan tidak hanya digunakan untuk mempersiapkan siswa dalam memperoleh profesi atau jabatan tetapi juga untuk dapat menyelesaikan masalah dalam kehidupan sehari-hari. Seperti halnya dalam pembelajaran geografi, proses pembelajarannya haruslah melibatkan proses mental siswa secara maksimal, bukan hanya menuntut siswa sekedar mendengar, mencatat, akan tetapi juga 
menghendaki aktivitas siswa dalam proses berfikir. Karena pembelajaran geografi dimaksudkan untuk mengembangkan kemampuan pemahaman terhadap fenomena sosial pada kehidupan sehari-hari. Selain itu, materi pelajaran geografi juga mencakup konsepkonsep dasar, pendekatan, metode, dan teknik analisis dalam pengkajian terhadap berbagai fenomena dan permasalahan yang ditemui dalam kehidupan nyata di masyarakat.

Sehubungan dengan kompleksnya mata pelajaran geografi sebagaimana disebutkan di atas maka geografi harus dipelajari atau diperoleh melalui proses belajar yang berlangsung secara kondusif sehingga siswa mampu mengembangkan kemampuan berpikir kritis dalam melihat fenomena sosial yang terjadi pada kehidupan sehari-hari berdasarkan sudut pandang geografi. Untuk mengetahui apakah siswa tersebut telah menguasai materi pembelajaran yang telah diajarkan adalah dengan meningkatnya hasil belajar siswa. Akan tetapi, fakta dilapangan menunjukkan bahwa hasil belajar siswa pada mata pelajaran geografi masih rendah. Permasalahan hasil belajar siswa pada mata pelajaran geografi masih rendah juga terjadi pada siswa kelas XI IPS 2 SMA Negeri 1 Buntulia. Berdasarkan hasil observasi yang telah dilakukan oleh peneliti sejak bulan Desember 2019, diketahui bahwa terdapat beberapa permasalahan di dalam kelas XI IPS 2 SMA Negeri 1 Buntulia yang mengakibatkan hasil belajar siswa pada mata pelajaran geografi masih rendah adalah 1) Siswa-siswi pada kelas tersebut masih bergaul secara berkelompok-kelompok sehingga belum bisa menyatu antara kelompok anak yang satu dengan yang lain; 2) Guru lebih sering menggunakan metode konvensional yang lebih mementingkan hasil daripada proses pembelajaran sehingga pembelajaran terkesan monoton; 3) Siswa juga sulit dalam memahami materi pembelajaran geografi karena mereka hanya dijelaskan sesuai yang ada pada buku pelajaran dan contoh yang diberikan sebagian besar juga sama seperti yang ada pada buku; 4) Keaktifan siswa dalam pembelajaran juga kurang; 5) Selain itu, dalam satu semester gasal ini, tercatat 5 (lima) siswa kelas XI IPS 2 yang mendapat Bimbingan Konseling (BK) mengenai prestasi belajarnya yang menurun; 6) Kemudian sebagian siswa yaitu 57.14\% atau 20 siswa kelas XI IPS 2 yang mengalami remidi atau tidak mencapai KKM pada mata pelajaran geografi saat ulangan mid semester gasal, dimana KKM (Kriteria Ketuntasan Minimal) pada mata pelajaran geografi di SMA Negeri 1 Buntulia adalah 75.

Fakta di atas menunjukkan hasil belajar siswa pada msata pelajaran geografi masih rendah sehingga salah satu jalan keluarnya adalah merubah model pembelajarannya dengan menerapkan model pembelajaran Problem Based Learning $(P B L)$ pada mata pelajaran geografi. Model pembelajaran Problem Based Learning atau pembelajaran berbasis masalah merupakan model pembelajaran yang berfokus kepada siswa atau student center. Model pembelajaran berbasis masalah tersebut bercirikhaskan mengenai masalah-masalah pada kehidupan nyata dan merupakan pembelajaran yang menekankan kepada aktivitas penyelidikan dalam memecahkan masalah tersebut. Dalam hal ini diharapkan, siswa dapat mengembangkan kemampuan berpikirnya karena ia akan memperoleh informasi dari berbagai sumber belajar mengenai materi yang sedang dipelajari. Selain itu, model pembelajaran berbasis masalah ini membagi siswa ke dalam kelompok-kelompok dengan permasalahan yang berbeda-beda pada masing-masing kelompok tersebut. Pembagian kelompok juga dilakukan secara heterogen sehingga diharapkan dapat memotivasi siswa untuk berinteraksi dengan siswa lain walaupun bukan peer groupnya, meningkatkan partisipasi, saling membantu, dan saling bekerjasama 
dalam berdiskusi memecahkan permasalahan yang mereka dapatkan serta berperan aktif di dalam pembelajaran geografi.

\section{METODE PENELITIAN}

Penelitian ini dilaksanakan di SMA Negeri 1 Buntulia yang beralamat di Jalan Trans Sulawesi Desa Duhiadaa Kec. Buntulia. Sementara kelas yang dijadikan penelitian adalah kelas XI IPS 2. Siswa kelas XI IPS 2 berjumlah 34 siswa, terdiri atas 15 siswa perempuan dan 19 siswa laki-laki. Pemilihan subjek penelitian didasarkan atas hasil belajar siswa yang masih rendah Penelitian ini dilaksanakan pada Tahun Pelajaran 2019/2020 semester genap. Penelitian ini dilakukan selama tujuh bulan yaitu mulai Desember 2019 sampai dengan Juni 2020.

Data yang diperlukan dalam penelitian ini adalah data kuantitatif yang diperoleh dari hasil tes serta hasil obeservasi selama kegiatan pembelajaran dan data kualitatif yang merupakan data yang berkaitan dengan kualitas, data tersebut berupa informasi tentang proses pembelajaran, aktivitas-aktivitas yang dilakukan oleh siswa maupun guru dalam proses pembelajaran. Data penelitian tersebut dikumpulkan dari berbagai sumber yang meliputi 1) peristiwa yaitu berlangsungnya proses atau kegiatan belajar mengajar mata pelajaran geografi di kelas XI IPS , 2) Informan yaitu guru Geografi kelas XI IPS 2 dan beberapa siswa kelas XI IPS 2 SMA Negeri 1 Buntulia, 3) Dokumen

Dalam penelitian tindakan kelas ini, peneliti menggunakan tiga teknik pengumpulan data. Adapun teknik pengumpulan data tersebut ialah observasi, wawancara, dan dokumentasi.

Teknik yang digunakan untuk memeriksa keabsahan data adalah dengan menggunakan Triangulasi Data (Trianggulasi sumber). Sutopo (2002: 79) menyatakan bahwa triangulasi sumber data yang memanfaatkan jenis sumber data yang berbeda-beda untuk menggali data yang sejenis".

Teknik analisis data yang digunakan dalam penelitian ini meliputi beberapa tahap yaitu 1) reduksi data yakni kegiatan tersebut berlangsung secara terus menerus selama penelitian itu diadakan Selama pengumpulan data dilakukan pula tahapan reduksi data atau pemilihan data, 2) penyajian data yakni data yang diperoleh disajikan dalam bentuk tulisan atau kata-kata, gambar, grafik maupun tabel, 3) penarikan simpulan yakni kegiatan penarikan simpulan akhir dilakukan dengan berdiskusi bersama guru mengenai hasil akhir yang diperoleh guna menentukan tindakan yang akan dilakukan selanjutnya. 


\section{HASIL PENELITIAN DAN PEMBAHASAN \\ Deskripsi Pratindakan}

Data kondisi awal yang diperoleh tersebut merupakan nilai mid semester gasal kelas XI IPS 2 yang masih rendah. Berdasarkan kondisi awal hasil belajar tersebut berikut tabel mengenai presentase ketuntasan hasil belajar pratindakan siswa kelas XI IPS 2 :

\section{Tabel Ketuntasan Hasil Belajar Pratindakan Siswa Kelas XI IPS 2}

\begin{tabular}{ccc}
\hline Ketuntasan & Jumlah Siswa & Presentase \\
\hline Tuntas & 15 & $42,86 \%$ \\
Tidak tuntas & 20 & $57,14 \%$ \\
\hline Jumlah & 35 & $100 \%$ \\
\hline Nilai rata-rata kelas & 71.82 & \\
\hline
\end{tabular}

\section{Deskripsi Siklus I dan Siklus II}

Setelah menerapkan model pembelajaran Problem Based Learning (PBL) pada hasil belajar siswa kelas XI IPS 2 secara keseluruhan mengalami peningkatan. Pernyataan tersebut dapat diperjelas pada tabel berikut :

Tabel Keseluruhan Hasil Belajar Ranah Afektif Kelas XI IPS 2

\begin{tabular}{cccc}
\hline Siklus 1 & Siklus 2 & Peningkatan & Keterangan \\
$62,28 \%$ & $80,58 \%$ & $18,30 \%$ & Meningkat
\end{tabular}

Tabel Keseluruhan Hasil Belajar Ranah Psikomotor Kelas XI IPS 2

\begin{tabular}{cccc}
\hline Siklus 1 & Siklus 2 & Peningkatan & Keterangan \\
\hline $60,57 \%$ & $80,29 \%$ & $19,72 \%$ & Meningkat
\end{tabular}


AKSARA: Jurnal Ilmu Pendidikan Nonformal

P-ISSN 2407-8018 E-ISSN 2721-7310 DOI prefix $\underline{10.37905}$

Volume 07, (03) September 2021

http://ejurnal.pps.ung.ac.id/index.php/Aksara

Tabel Keseluruhan Hasil Belajar Ranah Kognitif Kelas XI IPS 2

\section{Tindakan}

\begin{tabular}{lcccc} 
Hasil Belajar & Pra & Siklus 1 & Siklus 2 & Keterangan \\
& & & & \\
\hline Ketuntasan & $42,86 \%$ & $64,71 \%$ & $76,47 \%$ & Meningkat \\
\hline Nilai Rata- & 71.82 & 71.91 & 76.88 & Meningkat \\
rata kelas & & & & \\
\hline
\end{tabular}

Meskipun secara keseluruhan ketuntasan hasil belajar ranah kogitif dan nilai rata-rata kelas XI IPS 2 mengalami peningkatan tetapi apabila dilihat melalui hasil belajar ranah kognitif yang diperoleh setiap siswa tidak semua siswa mengalami peningkatan pada setiap siklusnya. Terdapat beberapa siswa yang mengalami penurunan nilai pada siklus 1 kemudian mengalami peningkatan pada siklus 2 dan terdapat pula siswa yang mengalami peningkatan pada siklus 1 kemudian mengalami penurunan pada siklus 2 .

Berdasarkan grafik tersebut diketahui bahwa terdapat beberapa siswa yang mengalami penurunan nilai pada siklus 1 kemudian mengalami peningkatan pada siklus 2 dan terdapat pula siswa yang mengalami peningkatan pada siklus 1 kemudian mengalami penurunan pada siklus 2 . Siswa yang selalu mengalami peningkatan pada setiap siklusnya adalah 7 siswa atau sebesar 20,59\%. Sementara jumlah siswa yang mengalami penurunan pada siklus 1 dan mengalami peningkatan pada siklus 2 adalah sebanyak 15 siswa atau sebesar $44,12 \%$. Sedangkan jumlah siswa yang mengalami peningkatan pada siklus 1 kemudian mengalami penurunan pada siklus 2 adalah sebanyak 12 siswa atau sebesar 35,29\% selain itu, tidak ada siswa yang mengalami penuruan pada setiap siklusnya. Perbedaan grafik yang diperoleh siswa kelas XI IPS 2 SMA Negeri 1 Buntulia dipengaruhi oleh beberapa factor baik dari segi guru maupun siswa sendiri. Selain itu, karakteristik setiap siswa yang berbeda-beda mengakibatkan perbedaan hasil yang diperoleh dari setiap siswa tersebut. Oleh sebab itu, dengan menggunakan satu model pembelajaran saja tidak dapat menggeneralisasi tingkat kemampuan siswa. Dengan demikian guru dapat menggunakan model pembelajaran lain yang lebih variatif dan inovatif untuk memperoleh hasil yang lebih optimal. 


\section{PENUTUP}

Model pembelajaran Problem Based Learning (PBL) mampu meningkatkan hasil belajar mata pelajaran geografi pada siswa kelas XI IPS 2 SMA Negeri 1 Buntulia Tahun Pelajaran 2019/2020.

Dalam hasil penelitian yang telah dilakukan ini menunjukkan bahwa hasil belajar afektif siswa pada siklus I yaitu sebesar $62,28 \%$ dan untuk siklus II sebesar 80,58\%. Peningkatan hasil belajar afektif yang terjadi dari siklus I ke siklus II adalah sebesar 18,30\% sehingga kategori hasil belajar afektif siswa kelas XI IPS 2 secara keseluruhan termasuk dalam kategori baik sekali atau optimal. Selain itu, hasil belajar psikomotor siswa pada siklus I diperoleh sebesar $60,57 \%$ dan untuk siklus II sebesar 80,29\%. Peningkatan hasil belajar psikomotor yang terjadi dari siklus I ke siklus II adalah sebesar 19,72\% maka kategori hasil belajar psikomotor siswa kelas XI IPS 2 secara keseluruhan juga termasuk dalam kategori baik sekali atau optimal. Sedangkan, ketuntasan hasil belajar kognitif siswa pada siklus I diperoleh sebesar 64,71\% dan untuk siklus II sebesar $76,47 \%$. Peningkatan ketuntasan hasil belajar kognitif yang terjadi dari siklus I ke siklus II adalah sebesar $11,76 \%$.

Berdasarkan hasil analisis hasil belajar ranah kognitif per siswa, diketahui bahwa siswa yang selalu mengalami peningkatan pada setiap siklusnya adalah 7 siswa atau sebesar $20,59 \%$. Sementara jumlah siswa yang mengalami penurunan pada siklus I dan mengalami peningkatan pada siklus II adalah sebanyak 15 siswa atau sebesar $44,12 \%$. Sedangkan jumlah siswa yang mengalami peningkatan pada siklus I kemudian mengalami penurunan pada siklus II adalah sebanyak 12 siswa atau sebesar 35,29\%. Dengan demikian menggunakan satu model pembelajaran saja tidak dapat menggeneralisasi tingkat kemampuan maupun karakteristik siswa yang heterogen sehingga guru dapat menggunakan model pembelajaran lain yang lebih variatif dan inovatif untuk memperoleh hasil yang lebih optimal.

\section{Saran}

Berdasarkan penelitian yang telah dilaksanakan, peneliti memiliki beberapa saran yang dapat dijabarkan sebagai berikut : 1)Bagi Guru yaitu, a) Guru hendaknya melakukan perencanaan dan pengelolaan waktu yang tepat apabila akan menggunakan model pembelajaran Problem Based Learning ( $P B L$ ) lagi sehingga proses pembelajaran dapat berjalan dengan efektif, b) Guru hendaknya lebih bervariatif dalam pemilihan model pembelajaran dan tidak hanya terpancang pada satu model pembelajaran saja ; 2) Bagi siswa, yaitu a) Siswa hendaknya tidak hanya terpancang pada sumber belajar yang diberikan oleh guru tetapi juga berusaha untuk mencari sumber belajar yang lain untuk menambah wawasan siswa, b) Siswa hendaknya lebih aktif dalam kegiatan diskusi maupun presentasi kelompok; 3) Bagi kepala sekolah, yaitu a) Kepala sekolah hendaknya membuat kebijakan kepada guru untuk melakukan penelitian tidakan kelas dalam rangka meningkatkan kualitas proses pembelajaran di kelas dengan menggunakan model pembelajaran yang lebih variatif dan inovatif, b) Kepala sekolah hendaknya meningkatkan fasilitas-fasilitas yang mendukung proses pembelajaran di kelas. 


\section{DAFTAR PUSTAKA}

Arends, R. I. (2008b). Learning To Teach Belajar Untuk Mengajar. Edisi Ketujuh. Buku Dua. Terj. Helly Prajitno Soetjipto \& Sri Mulyantini Soetjipto. Yogyakarta: Pustaka Belajar.

Arikunto, S., Suhardjono, \& Supardi. (2006). Penelitian Tindakan Kelas. Jakarta: Bumi Aksara.

Basrowi. (2008). Prosedur Penelitian Tindakan Kelas. Jakarta: Ghalia Indonesia.

Dimyati \& Mudjiono. (2002). Belajar Dan Pembelajaran. Jakarta: Rineka Cipta.

Kasbolah, K. (2001). Penelitian Tindakan Kelas. Malang: Universitas Negeri Malang.

Madya, S. (2007). Teori Dan Praktik Penelitian Tindakan (Action Research). Bandung: Alfabeta.

Rusman. (2012). Model-Model Pembelajaran Mengembangkan Profesionalisme Guru. Jakarta: Raja Grafindo Persada.

Sudijono, A. (2008). Pengantar Evaluasi Pendidikan. Jakarta: Raja Grafindo Persada.

Sudjana, N. (2009). Penilaian Hasil Proses Belajar Mengajar. Bandung: Remaja Rosdakarya.

Suprijono, A. (2009). Cooperative Learning Teori dan Aplikasi PAIKEM. Yogyakarta: Pustaka Belajar. 
AKSARA: Jurnal Ilmu Pendidikan Nonformal

P-ISSN 2407-8018 E-ISSN 2721-7310 DOI prefix $\underline{10.37905}$

Volume 07, (03) September 2021

http://ejurnal.pps.ung.ac.id/index.php/Aksara

1222 AKSARA: Jurnal Ilmu Pendidikan Nonformal 